\title{
Effect of Feeding Shatavari (Asparagus racemosus) Root Powder on Qualitative and Quantitative Parameter of Milk in Crossbred Cows
}

\author{
Vijay Prakash Saini ${ }^{*}$, Sheela Choudhary ${ }^{2}$, Reenu Tanwar ${ }^{2}$, Sunil Dutt Choudhary $^{3}$, \\ Surya Prakash Sirvi ${ }^{2}$ and Vikram Singh Yadav ${ }^{2}$
}
${ }^{1}$ Mahatma Jyotiba Fule College of Veterinary \& Animal Sciences Chomu, Jaipur-303702, India
${ }^{2}$ Department of Animal Nutrition, Post Graduate Institute of Veterinary Education and Research, Jaipur - 302031, India
${ }^{3}$ Department of Animal Husbandry, Bhakarpura, Barmer - 344031, India

*Corresponding author

\section{A B S T R A C T}

\begin{tabular}{|l|}
\hline K e y w o r d s \\
Milk fat, Milk lactose, \\
Milk protein, Milk \\
yield and Shatavari \\
\hline Article Info \\
\hline Accepted: \\
17 July 2018 \\
Available Online: \\
10 August 2018 \\
\hline
\end{tabular}

The present study was conducted to evaluate the effect of herbal feed supplement shatavari (Asparagus racemosus) in terms of qualitative and quantitative parameters of milk, in crossbred cows. The cows were divided in four groups. Group $\mathrm{G}_{1}$ was control group, in which the animals receive experimental feed without any other feed supplements, whereas the animals of experimental group $2\left(\mathrm{G}_{2}\right)$, group $3\left(\mathrm{G}_{3}\right)$ and group $4\left(\mathrm{G}_{4}\right)$ were fed a similar feed along with shatavari root powder $40 \mathrm{gm}, 80 \mathrm{gm}$ and $120 \mathrm{gm}$ respectively. The study was conducted for a period of 60 days including 7 days digestibility trial. Daily milk yield was also recorded. Milk composition of each animal was determined once every fortnight. Cows fed shatavari (Asparagus racemosus) root powder produce more milk $(\mathrm{P} \leq 0.01)$ and milk fat per cent, milk fat yield, milk protein per cent, milk protein yield, milk lactose per cent, milk lactose yield, milk solid not fat per cent, milk solid not fat yield, milk total solid per cent and milk total solid yield content $(\mathrm{P}<0.01)$ than control cows.

\section{Introduction}

Livestock sector plays a vital role in the rural economy as providing family income and generating gainful employment in the rural sector. Livestock contributes $3.9 \%$ in total GDP during the year of 2013-14. India is leading country in total milk production.

Milk production in India is 137.7 million tonnes in 2013-14 and per capita availability is 307 gm/day in 2014-15 (DADF, 2015). During the last two decades, India has emerged as world's top most nations in the dairy sector and has witnessed rapid development in the milk production. On other hands, the productivity of dairy animals in India is very low because of various factors like underfeeding, malnutrition, various diseases, stress etc. which hamper the economy of the dairy industry. With the demand for organic food and ban on the use of certain antibiotics, harmful residual effects and cost effectiveness in the livestock feed, the search for alternative feed additives has become the necessity of the day. 
Herbal feed additives could either effect feeding pattern, or effect the growth of favourable microorganisms in the rumen, or stimulate the secretion of different digestive enzymes, which in turn may improve the efficiency of nutrients utilization or stimulate the milk secreting tissue in the mammary glands, resulting in improved productive and reproductive performance of dairy animals (Bakshi and Wadhwa, 2000). A medicinal herb has properties to improve digestibility, antibacterial, immuno-stimulation, coccidiostatic, anthelmintic, antiviral orantioxidative (Uegaki et al., 2001).

Herbals are concentrated foods those provide vitamins, minerals and other nutrients that sustain and strengthen the human and animal body. Indian history is very rich in herbal medicine and one of the oldest surviving systems of healthcare in the world known as Ayurveda. Ayurveda is a natural therapy and totally based on herbs. These herbs were being used since pre-vedic time because they were safe to use, cheap and easily available, has no side effect and no residual effect in milk (Krishna et al., 2005). So, their inclusion in the diet should be encouraged to enhance animal's performance, improve feed efficiency, maintain health and alleviate adverse effect of environmental stress. Traditional herbal medicines in veterinary practice have a large potential as an alternate therapy. According to Bakshi et al., (2004), herbal plants were broadly used as animal feed additives, having galactogogue properties like Shatavari (Asparagus racemosus), Jivanti (Leptadenia reticulata) and Methi (Trigonella foenum).

A galactogogue is a substance that promotes lactation in dairy animals. It may be synthetic, plant-derived, or endogenous. They act through exerting an influence on an adrenohypothalamohypophyseal-gonadal axis by inhibiting hypothalamic dopaminergic receptors or by inhibiting dopamine producing neurons. These medications increase prolactin secretion by antagonizing dopamine receptors (Gabay, 2002). Galactogogues stimulate the activity of alveolar tissue and raise the secretory activity and thereby restore and regulate milk yield (Ravikumar and Bhagwat, 2008). Animal production can be enhanced by using different herbals as a component of animal feed.

\section{Materials and Methods}

The study was taken up in Jaipur district of Rajasthan. Sixteen crossbred cows of almost same stage of lactation and milk yield were selected and distributed into four groups of four each from the herd of Shri Pinjarapole Gaushala, Sanganer, Jaipur. All the cows were maintained under stall feeding.

\section{Housing and management of cows}

All crossbred cows were housed in a wellventilated byre having concrete floor with individual feeding arrangement and tied with iron chain at such a distance that they had freedom for free movement but preventing them to access the manger of other cows. All the crossbred cows under the present study had their identification number uniquely tagged on the ear. Cows were stall fed throughout the experimental period. Fresh and clean water was provided thrice a day i.e. morning, afternoon and evening throughout the experimentation. Animals were given prophylactic dose of anthelmintic 15 days prior to start of experiment. Proper hygienic conditions and healthy surrounding were maintained in the shed throughout the experimental feeding period. During the research period, health status of cows was monitored regularly. Crossbred cows were fed as per ICAR (2013) feeding standards to meet the requirement of nutrients for 60 days. Wheat straw was offered daily ad lib in 
morning. The leftover was removed on the next day morning. Shatavari root powder was supplemented daily by mixing in the concentrate. An adaptation period of 15 days was observed prior to start of experimental feeding trial.

Thereafter, cows were distributed into four groups of four animals each in such a way that each group had almost similar stage of lactation and milk yield. Cows were then placed on four dietary experimental feeds (Table 1). Deworming of the cows was done twice by fenbendazole bolus at an interval of two weeks and shatavari root powder feeding was initiated after second deworming.

The experimental group $\mathrm{G}_{1}$ that was control group receiving experimental feed consisting of wheat straw and readymade concentrates. Crossbred cows of the experimental group $\mathrm{G}_{2}$ were fed wheat straw and readymade concentrate with shatavari root powder @ 40 $\mathrm{gm} /$ day/cow for 60 days.

Crossbred cows of the experimental group $\mathrm{G}_{3}$ were fed wheat straw and readymade concentrate with shatavari root powder@80 $\mathrm{gm} /$ day/cow for 60 days.

Crossbred cows of the experimental group $\mathrm{G}_{4}$ were fed wheat straw and readymade concentrate with shatavari root powder @ 120 gm/day/cow for 60 days. The shatavari root powder was made available by Nutri Care Animal Feed, Sanganer, Jaipur.

\section{Collection of milk samples}

Milking of cows was done twice daily at 5:00 AM and 4:00 PM by the milkers at the milking barn. Milk yields were recorded in kilogram (kg) by using digital weighing balance. Milk samples of crossbred cows were collected fortnightly on $0,15,30,45$ and 60 days in the morning and evening.

\section{Milk yield and related parameters}

Under this following parameters were calculated:-

Milk yield (kg) - Daily milk yield was recorded in $\mathrm{kg}$ at each milking and then fortnightly average milk yield was calculated.

Milk fat (per cent) - The fat per cent in the milk was measured fortnightly for individual cow.

Milk fat yield $(\mathrm{kg})$ - The fortnightly milk fat yield of fat was calculated by multiplying the fortnightly milk yield with fortnightly fat per cent and divided by 100 .

Milk protein (per cent) - Milk protein per cent was calculated fortnightly for individual cow.

Milk protein yield $(\mathrm{kg})$ - The fortnightly milk protein yield was calculated by multiplying

The fortnightly milk yield with fortnightly protein per cent and divided by 100 .

Fortnightly milk lactose (per cent) - Milk lactose per cent was calculated fortnightly for individual cow.

Milk lactose yield $(\mathrm{kg})$ - The fortnightly yield of milk lactose was calculated by multiplying the fortnightly milk yield with fortnightly lactose per cent and divided by 100 .

Milk solid not fat (per cent) - The solid not fat per cent in milk was measured fortnightly for individual cow.

Milk solid not fat yield $(\mathrm{kg})$ - The fortnightly milk solid not fat yield was calculated by multiplying the fortnightly milk yield with fortnightly milk solid not per cent and divided by 100 . 
Milk total solid (per cent) - The milk total solid per cent was calculated fortnightly for individual cow.

Milk total solid yield (kg) - The fortnightly yield of milk total solid was calculated by multiplying the fortnightly milk yield with fortnightly milk total solid per cent and divided by 100 . Milk composition viz. milk fat, milk protein, milk lactose, milk solid not fat and milk total solid was analysed by automatic milk analyzer FOSS Milkoscan ${ }^{\text {TM }}$ FT1.

\section{Results and Discussion}

\section{Quantitative milk parameter}

\section{Milk yield}

The statistical analysis of data revealed highly significant $(\mathrm{P} \leq 0.01)$ effect of treatment on daily milk yield and is presented in Table 2 . Effect of period was found to be nonsignificant. Milk yield increased significantly in all treatment groups, however there is no significant difference among all treatment groups. Experimental results are well supported by Ramesh et al., (2000), Mishra et al., (2008), Tanwar et al., (2008) and Divya et al., (2015).

\section{Qualitative milk parameter}

\section{Milk fat}

The statistical analysis of data revealed highly significant $(\mathrm{P} \leq 0.01)$ effect of treatment on milk fat and is presented in Table 3. Effect of period was found to be highly significant $(\mathrm{P} \leq 0.01)$. These results are corroborated with the findings of Shridhar and Bhagwat (2007) who reported that Galactin Vet Bolus improved fat per cent in dairy cows. Similar results were also reported by Soni (2014), who reported significant $(\mathrm{P} \leq 0.01)$ improvement, in fat of kankrej cows supplemented with shatavari (Asparagus racemosus) during postpartum period.

\section{Milk fat yield}

Statistical analysis of data revealed highly significant $(\mathrm{P} \leq 0.01)$ effect of treatment on milk fat yield and is presented in Table 4. Effect of period was also found to be significant $(\mathrm{P} \leq 0.05)$. The results were in agreement with Soni (2014), who reported highly significant $(\mathrm{P} \leq 0.01)$ effect of shatavari supplementation on milk fat yield in kankrej cows.

\section{Milk protein}

The statistical analysis of data revealed highly significant $(\mathrm{P} \leq 0.01)$ effect of treatment on milk protein and is presented in Table 5. Effect of period was also found to be significant $(\mathrm{P} \leq 0.01)$. These results are in accordance with Soni (2014), who observed highly significant $(\mathrm{P} \leq 0.01)$ effect of shatavari supplementation on protein per cent in kankrej cows. Divya et al., (2015) also reported significant effect of shatavari on protein per cent in indigenous cows.

\section{Milk protein yield}

Statistical analysis of data revealed highly significant $(\mathrm{P} \leq 0.01)$ effect due to treatment and is presented in Table 6. Effect of period was also found to be significant $(\mathrm{P} \leq 0.05)$. The results are in accordance with Soni (2014), who reported highly significant $(\mathrm{P} \leq 0.01)$ effect of shatavari supplementation on protein yield in kankrej cows.

\section{Milk lactose}

The statistical analysis of data revealed highly significant $(\mathrm{P} \leq 0.01)$ effect on milk lactose due to treatment and is presented in Table 7. 
Table.1 Experimental feeds offered to crossbred cows in different groups

\begin{tabular}{|c|}
\hline Experiment \\
\hline $\mathrm{G}_{1}$ \\
\hline $\mathbf{G}_{2}$ \\
\hline $\mathbf{G}_{3}$ \\
\hline $\mathbf{G}_{4}$ \\
\hline
\end{tabular}

\begin{tabular}{|c|} 
Experimental feed \\
\hline $\begin{array}{c}\text { Wheat straw + Readymade concentrate } \\
\text { (without shatavari root powder })\end{array}$ \\
\hline Wheat straw + Readymade concentrate + \\
Shatavari root powder $(40$ gm/day/animal $)$ \\
\hline Wheat straw + Readymade concentrate + \\
Shatavari root powder $(80$ gm/day/animal $)$ \\
Wheat straw + Readymade concentrate + \\
Shatavari root powder $(120$ gm/day/animal $)$
\end{tabular}

Table.2 Mean \pm S.E.M. values of milk yield (kg/day) in different treatment groups

\begin{tabular}{|c|c|c|c|c|c|c|c|}
\hline & \multicolumn{5}{|c|}{ Proup } & \multicolumn{5}{|c|}{ Overall } & SEM \\
\hline & $\mathbf{0}$ & $\mathbf{1 5}$ & $\mathbf{3 0}$ & $\mathbf{4 5}$ & $\mathbf{6 0}$ & \\
\hline $\mathbf{G}_{\mathbf{1}}$ & 7.41 & 7.21 & 7.22 & 6.66 & 6.27 & $6.96^{\mathrm{a}}$ & \\
\hline $\mathbf{G}_{\mathbf{2}}$ & 7.33 & 7.94 & 8.56 & 8.74 & 8.82 & $8.27^{\mathrm{b}}$ & 0.19 \\
\hline $\mathbf{G}_{\mathbf{3}}$ & 7.44 & 8.14 & 8.60 & 8.88 & 8.90 & $8.39^{\mathrm{b}}$ & \\
\hline $\mathbf{G}_{\mathbf{4}}$ & 7.36 & 8.22 & 8.58 & 8.62 & 8.85 & $8.33^{\mathrm{b}}$ & \\
\hline
\end{tabular}

Means with different superscripts differ significantly within the column

Table.3 Mean \pm S.E.M. values of milk fat (per cent) in different treatment groups

\begin{tabular}{|c|c|c|c|c|c|c|c|}
\hline \multirow[t]{2}{*}{ Group } & \multicolumn{5}{|c|}{ Period in days } & \multirow[t]{2}{*}{ Overall mean } & \multirow[t]{2}{*}{ SEM } \\
\hline & $\mathbf{0}$ & 15 & 30 & 45 & 60 & & \\
\hline $\mathbf{G}_{1}$ & 3.96 & 4.02 & 4.05 & 4.05 & 4.05 & $4.03^{\mathrm{a}}$ & \\
\hline $\mathbf{G}_{2}$ & 4.13 & 4.19 & 4.38 & 4.39 & 4.50 & $4.32^{b}$ & 0.06 \\
\hline $\mathbf{G}_{3}$ & 3.99 & 4.04 & 4.24 & 4.42 & 4.63 & $4.26^{b}$ & \\
\hline $\mathbf{G}_{4}$ & 4.10 & 4.39 & 4.60 & 4.73 & 5.11 & $4.58^{c}$ & \\
\hline
\end{tabular}

Means with different superscripts differ significantly within the column 
Table.4 Mean \pm S.E.M. values of milk fat yield $(\mathrm{kg})$ in different treatment groups

\begin{tabular}{|c|c|c|c|c|c|c|c|}
\hline \multirow[t]{2}{*}{ Group } & \multicolumn{5}{|c|}{ Period in days } & \multirow[t]{2}{*}{ Overall mean } & \multirow[t]{2}{*}{ SEM } \\
\hline & $\mathbf{0}$ & 15 & 30 & 45 & 60 & & \\
\hline $\mathbf{G}_{1}$ & 0.29 & 0.28 & 0.29 & 0.27 & 0.25 & $0.28^{\mathrm{a}}$ & \\
\hline $\mathbf{G}_{2}$ & 0.30 & 0.33 & 0.37 & 0.38 & 0.39 & $0.35^{b}$ & 0.017 \\
\hline $\mathbf{G}_{3}$ & 0.29 & 0.32 & 0.36 & 0.39 & 0.41 & $0.35^{b}$ & \\
\hline $\mathbf{G}_{4}$ & 0.30 & 0.36 & 0.39 & 0.40 & 0.45 & $0.38^{\mathrm{b}}$ & \\
\hline
\end{tabular}

Means with different superscripts differ significantly within the column

Table.5 Mean \pm S.E.M. values of milk protein (per cent) in different treatment groups

\begin{tabular}{|c|c|c|c|c|c|c|c|}
\hline \multirow[t]{2}{*}{ Group } & \multicolumn{5}{|c|}{ Period in days } & \multirow[t]{2}{*}{ Overall mean } & \multirow[t]{2}{*}{ SEM } \\
\hline & $\mathbf{0}$ & 15 & 30 & 45 & 60 & & \\
\hline $\mathbf{G}_{1}$ & 3.25 & 3.33 & 3.58 & 3.44 & 3.31 & $3.38^{\mathrm{a}}$ & \\
\hline $\mathbf{G}_{2}$ & 3.18 & 3.65 & 3.72 & 4.07 & 3.92 & $3.71^{b}$ & 0.05 \\
\hline $\mathbf{G}_{3}$ & 3.24 & 3.46 & 3.70 & 4.11 & 3.86 & $3.67^{b}$ & \\
\hline $\mathbf{G}_{4}$ & 3.18 & 3.57 & 3.74 & 4.14 & 3.86 & $3.70^{b}$ & \\
\hline
\end{tabular}

Means with different superscripts differ significantly within the columns

Table.6 Mean \pm S.E.M. values of milk protein yield $(\mathrm{kg})$ in different treatment groups

\begin{tabular}{|c|c|c|c|c|c|c|c|}
\hline \multirow[t]{2}{*}{ Group } & \multicolumn{5}{|c|}{ Period in days } & \multirow[t]{2}{*}{ Overall mean } & \multirow[t]{2}{*}{ SEM } \\
\hline & $\mathbf{0}$ & 15 & 30 & 45 & 60 & & \\
\hline $\mathbf{G}_{1}$ & 0.24 & 0.24 & 0.25 & 0.23 & 0.20 & $0.23^{\mathrm{a}}$ & \\
\hline $\mathbf{G}_{2}$ & 0.23 & 0.29 & 0.31 & 0.35 & 0.34 & $0.30^{\mathrm{b}}$ & 0.018 \\
\hline $\mathbf{G}_{3}$ & 0.24 & 0.28 & 0.31 & 0.36 & 0.34 & $0.31^{\mathrm{b}}$ & \\
\hline $\mathbf{G}_{4}$ & 0.23 & 0.29 & 0.32 & 0.35 & 0.34 & $0.30^{\mathrm{b}}$ & \\
\hline
\end{tabular}

Means with different superscripts differ significantly within the column

Table.7 Mean \pm S.E.M. values of milk lactose (per cent) in different treatment groups

\begin{tabular}{|c|c|c|c|c|c|c|c|}
\hline & \multicolumn{5}{|c|}{ Period in days } & Overall mean & SEM \\
\hline & $\mathbf{0}$ & $\mathbf{1 5}$ & $\mathbf{3 0}$ & $\mathbf{4 5}$ & $\mathbf{6 0}$ & \\
\hline $\mathbf{G}_{\mathbf{1}}$ & 4.53 & 4.73 & 4.82 & 4.43 & 4.65 & $4.63^{\mathrm{a}}$ & \\
\hline $\mathbf{G}_{\mathbf{2}}$ & 4.56 & 4.95 & 4.82 & 4.95 & 4.88 & $4.83^{\mathrm{ab}}$ & 0.05 \\
\hline $\mathbf{G}_{\mathbf{3}}$ & 4.86 & 5.25 & 5.06 & 5.22 & 5.16 & $5.11^{\mathrm{c}}$ & \\
\hline $\mathbf{G}_{\mathbf{4}}$ & 4.78 & 5.18 & 5.01 & 5.13 & 4.93 & $5.01^{\mathrm{bc}}$ & \\
\hline
\end{tabular}

Means with different superscripts differ significantly within the column 
Table.8 Mean \pm S.E.M. values of milk lactose yield $(\mathrm{kg})$ in different treatment groups

\begin{tabular}{|c|c|c|c|c|c|c|c|}
\hline \multirow[t]{2}{*}{ Group } & \multicolumn{5}{|c|}{ Period in days } & \multirow[t]{2}{*}{ Overall mean } & \multirow[t]{2}{*}{ SEM } \\
\hline & $\mathbf{0}$ & 15 & 30 & 45 & 60 & & \\
\hline $\mathbf{G}_{1}$ & 0.33 & 0.34 & 0.34 & 0.29 & 0.29 & $0.32^{\mathrm{a}}$ & \\
\hline $\mathbf{G}_{2}$ & 0.33 & 0.39 & 0.41 & 0.43 & 0.43 & $0.40^{\mathrm{b}}$ & 0.016 \\
\hline $\mathbf{G}_{3}$ & 0.36 & 0.42 & 0.43 & 0.46 & 0.46 & $0.43^{b}$ & \\
\hline $\mathbf{G}_{4}$ & 0.35 & 0.42 & 0.43 & 0.44 & 0.44 & $0.42^{b}$ & \\
\hline
\end{tabular}

Means with different superscripts differ significantly within the column

Table.9 Mean \pm S.E.M. values of milk solid not fat (per cent) in different treatment group

\begin{tabular}{|c|c|c|c|c|c|c|c|}
\hline \multirow[t]{2}{*}{ Group } & \multicolumn{5}{|c|}{ Period in days } & \multirow[t]{2}{*}{ Overall mean } & \multirow[t]{2}{*}{ SEM } \\
\hline & $\mathbf{0}$ & 15 & 30 & 45 & 60 & & \\
\hline $\mathbf{G}_{1}$ & 8.83 & 8.64 & 8.84 & 8.87 & 8.85 & $8.80^{\mathrm{a}}$ & \\
\hline $\mathbf{G}_{2}$ & 8.75 & 9.01 & 8.93 & 9.09 & 8.96 & $8.95^{\mathrm{b}}$ & 0.07 \\
\hline $\mathbf{G}_{3}$ & 8.87 & 9.22 & 9.20 & 9.38 & 9.21 & $9.18^{\mathrm{d}}$ & \\
\hline $\mathbf{G}_{4}$ & 8.70 & 9.29 & 9.91 & 9.05 & 9.15 & $9.08^{\mathrm{c}}$ & \\
\hline
\end{tabular}

Means with different superscripts differ significantly within the column

Table.10 Mean \pm S.E.M. values of milk solid not fat yield $(\mathrm{kg})$ in different treatment groups

\begin{tabular}{|c|c|c|c|c|c|c|c|}
\hline \multirow[t]{2}{*}{ Group } & \multicolumn{5}{|c|}{ Period in days } & \multirow[t]{2}{*}{ Overall mean } & \multirow[t]{2}{*}{ SEM } \\
\hline & $\mathbf{0}$ & 15 & 30 & 45 & 60 & & \\
\hline $\mathbf{G}_{1}$ & 0.65 & 0.62 & 0.64 & 0.59 & 0.55 & $0.61^{\mathrm{a}}$ & \\
\hline $\mathbf{G}_{2}$ & 0.64 & 0.71 & 0.76 & 0.79 & 0.79 & $0.74^{b}$ & 0.04 \\
\hline $\mathbf{G}_{3}$ & 0.66 & 0.75 & 0.79 & 0.83 & 0.82 & $0.77^{b}$ & \\
\hline $\mathbf{G}_{4}$ & 0.64 & 0.76 & 0.79 & 0.78 & 0.81 & $0.76^{b}$ & \\
\hline
\end{tabular}

Means with different superscripts differ significantly within the column

Table.11 Mean \pm S.E.M. values of milk total solid (per cent) in different treatment groups

\begin{tabular}{|c|c|c|c|c|c|c|c|}
\hline & \multicolumn{5}{|c|}{ Proup } & \multicolumn{5}{|c|}{ Overall mean } & SEM \\
\hline & $\mathbf{0}$ & $\mathbf{1 5}$ & $\mathbf{3 0}$ & $\mathbf{4 5}$ & $\mathbf{6 0}$ & \\
\hline $\mathbf{G}_{\mathbf{1}}$ & 13.29 & 13.72 & 13.39 & 13.60 & 13.18 & $13.43^{\mathrm{a}}$ & \\
\hline $\mathbf{G}_{\mathbf{2}}$ & 14.36 & 15.34 & 14.61 & 15.49 & 14.86 & $14.93^{\mathrm{b}}$ & 0.22 \\
\hline $\mathbf{G}_{\mathbf{3}}$ & 13.36 & 14.09 & 14.11 & 14.72 & 14.11 & $14.08^{\mathrm{a}}$ & \\
\hline $\mathbf{G}_{\mathbf{4}}$ & 14.17 & 15.43 & 15.60 & 14.51 & 14.96 & $14.93^{\mathrm{b}}$ & \\
\hline
\end{tabular}

Means with different superscripts differ significantly within the column 
Table.12 Mean \pm S.E.M. values of milk total solid yield $(\mathrm{kg})$ in different treatment groups

\begin{tabular}{|c|c|c|c|c|c|c|c|}
\hline \multirow[t]{2}{*}{ Group } & \multicolumn{5}{|c|}{ Period in days } & \multirow[t]{2}{*}{ Overall mean } & \multirow[t]{2}{*}{ SEM } \\
\hline & $\mathbf{0}$ & 15 & 30 & 45 & 60 & & \\
\hline $\mathbf{G}_{1}$ & 0.99 & 0.99 & 0.96 & 0.90 & 0.82 & $0.94^{\mathrm{a}}$ & \\
\hline $\mathbf{G}_{2}$ & 1.05 & 1.21 & 1.25 & 1.35 & 1.31 & $1.24^{\mathrm{b}}$ & 0.04 \\
\hline $\mathbf{G}_{3}$ & 0.99 & 1.15 & 1.21 & 1.35 & 1.31 & $1.18^{\mathrm{ab}}$ & \\
\hline $\mathbf{G}_{4}$ & 1.04 & 1.27 & 1.34 & 1.25 & 1.32 & $1.25^{\mathrm{b}}$ & \\
\hline
\end{tabular}

Means with different superscripts differ significantly within the column
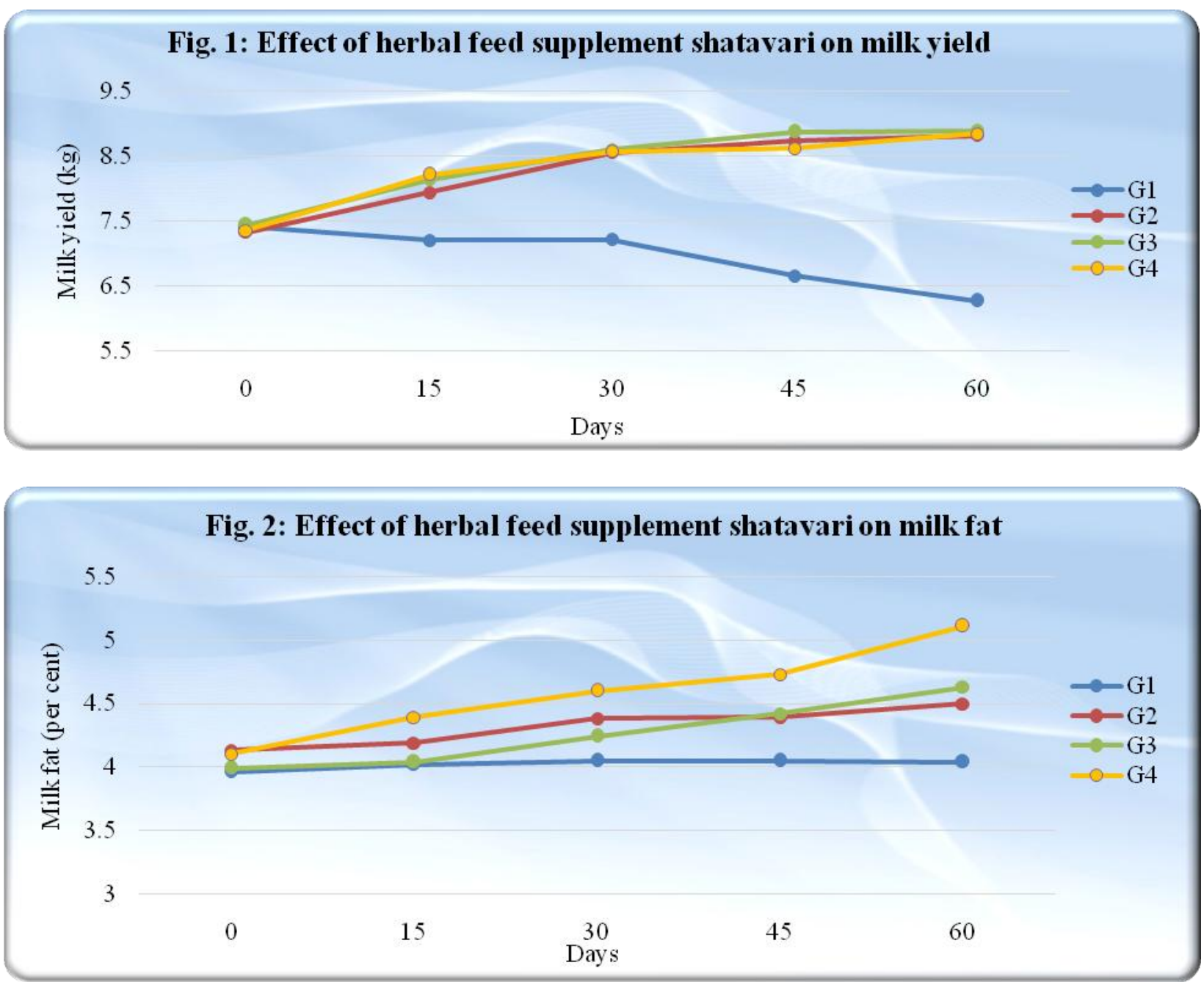


\section{Fig. 3: Effect of herbal feed supplement shatavari on milk fat yield}

$$
\begin{aligned}
& 0.5
\end{aligned}
$$

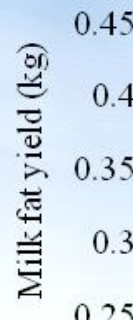

$$
\begin{aligned}
& 0.2
\end{aligned}
$$

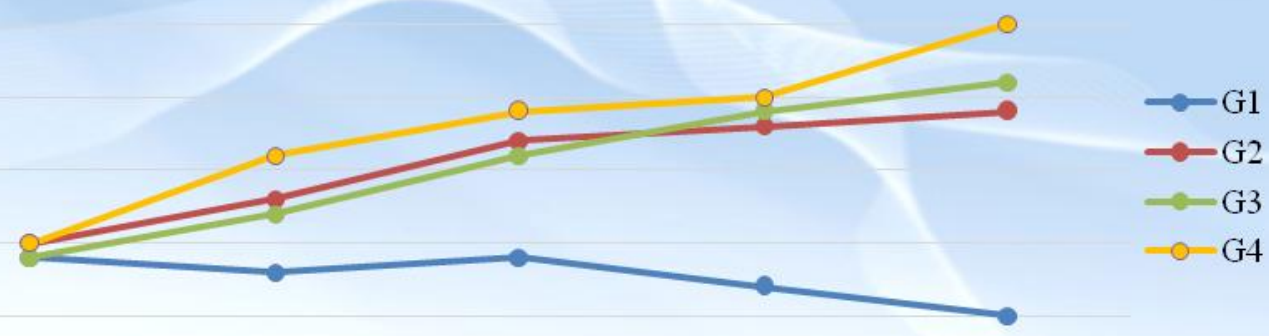

0

15

30

45

60

Fig. 4: Effect of herbal feed supplement shatavari on milk protein
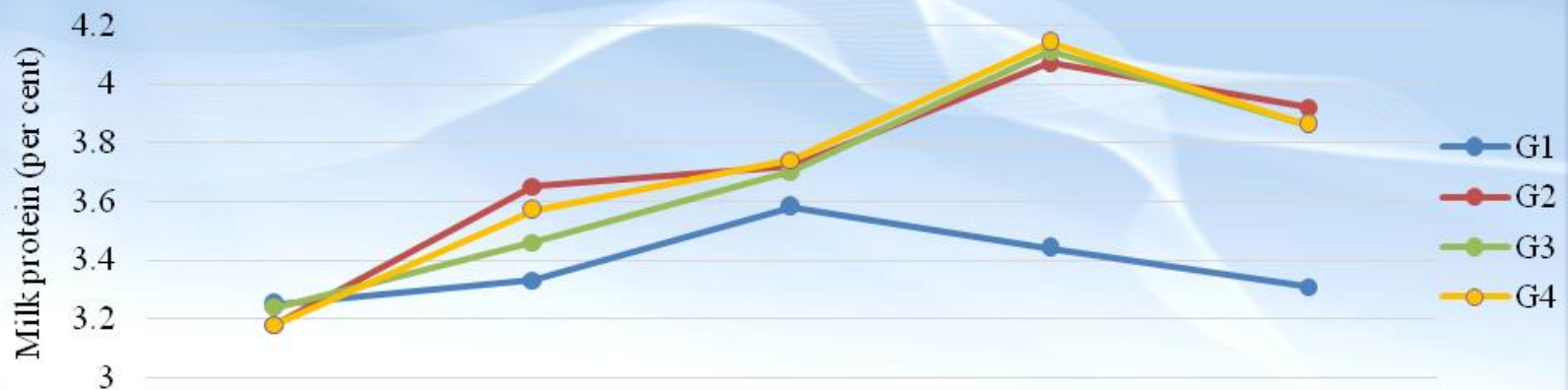

0

15

30
Days

45

60

Fig. 5: Effect of herbal feed supplement shatavari on milk protein yield

0.4

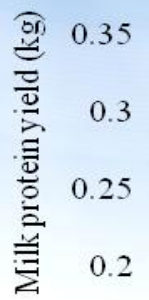

0.15

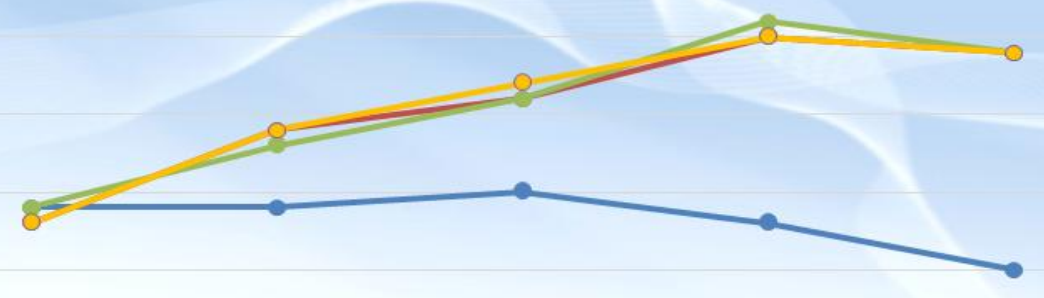

$\rightarrow \mathrm{G} 1$

$\longrightarrow \mathrm{G} 2$

$\longrightarrow \mathrm{G} 3$

$-\circ-\mathrm{G} 4$

0

15

30

45

60 
Fig. 6: Effect of herbal feed supplement shatavari on milk lactose
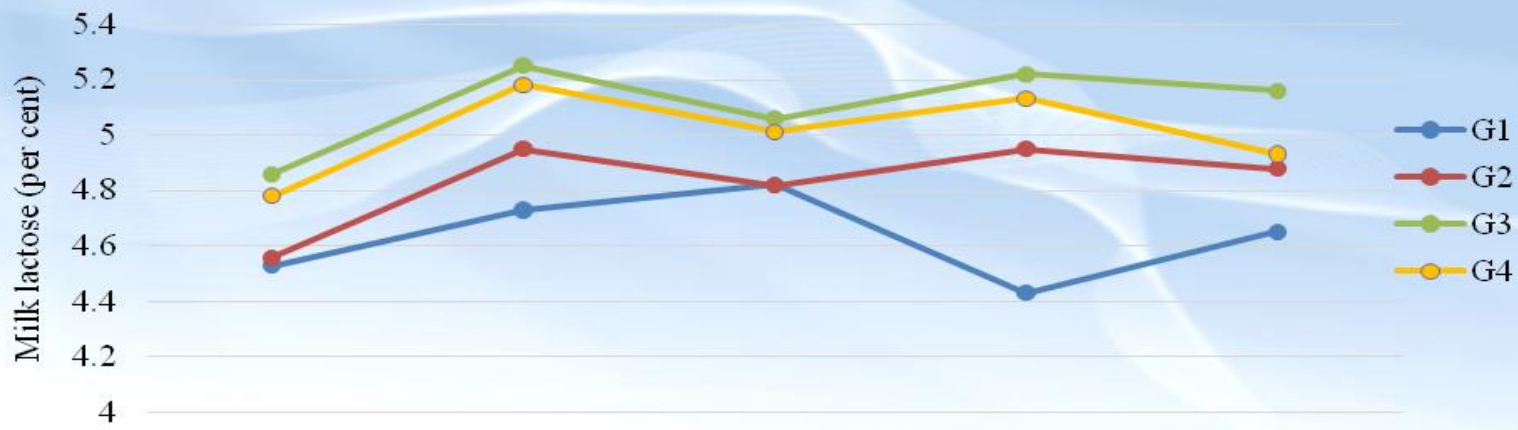

0

15

30

45

60

Fig 7: Effect of herbal feed supplement shatavari on milk lactose yield

0.5

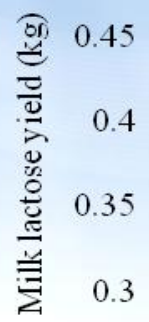

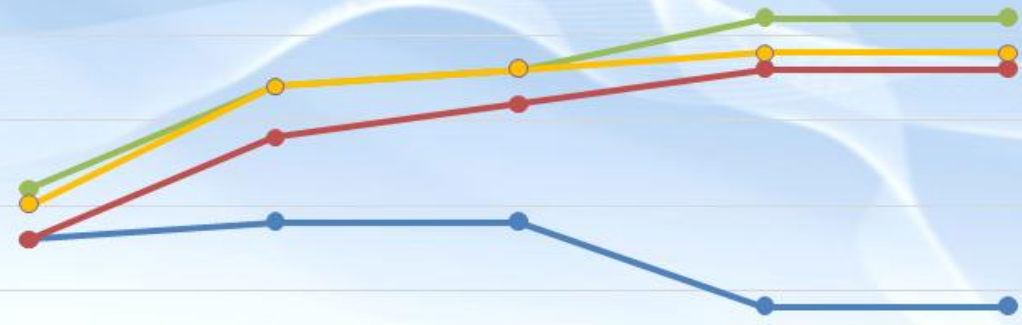

0.25

0

15

30

45

60

Days

Fig 8: Effect of herbal feed supplement shatavari on milk solid not fat
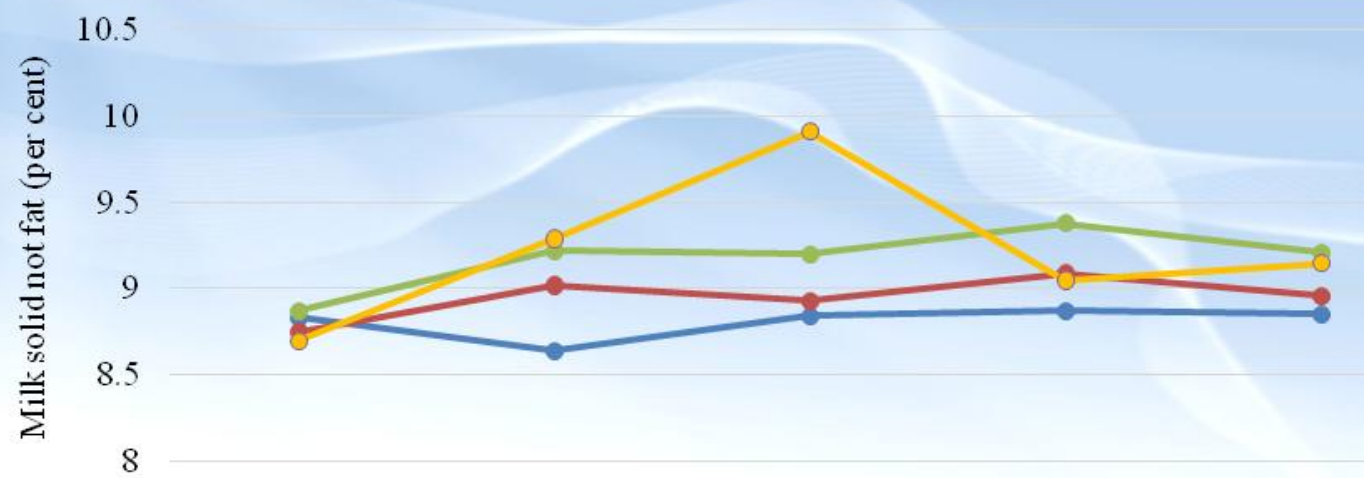

0

15

30

45

60 

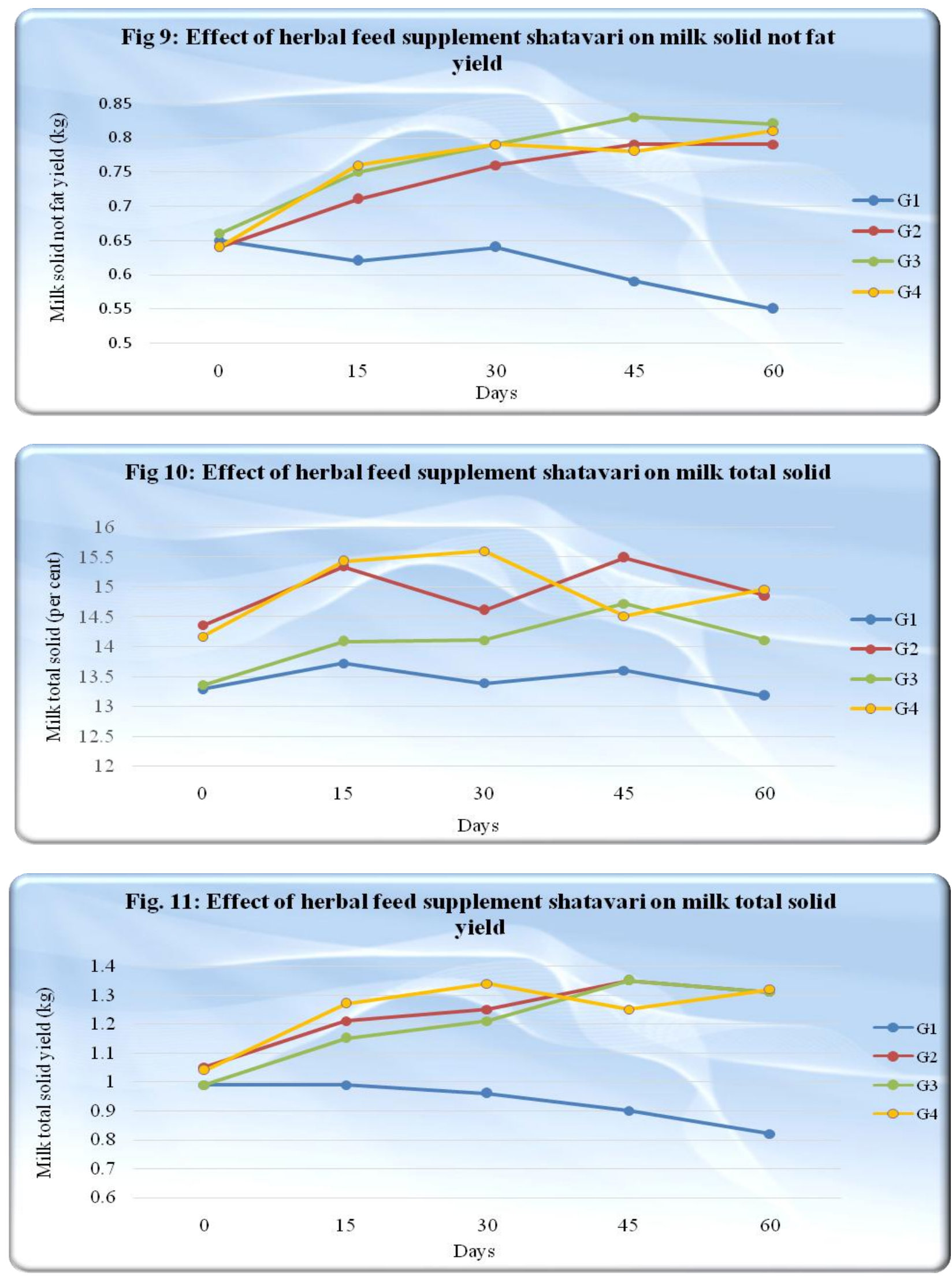
Effect of period was also found to be significant $\quad(\mathrm{P} \leq 0.05)$. Soni $\quad(2014)$, who reported non-significant effect of shatavari supplementation on milk lactose percentage in kankrej cows.

\section{Milk lactose yield}

The statistical analysis of data revealed highly significant $(\mathrm{P} \leq 0.01)$ effect of treatment on milk lactose yield and is presented in Table 8 . Effect of period was found to be nonsignificant. Soni (2014) also reported highly significant $\quad(\mathrm{P} \leq 0.01) \quad$ effect of shatavari supplementation on milk lactose yield in kankrej cows.

\section{Milk solid not fat}

The statistical analysis of data revealed highly significant $(\mathrm{P} \leq 0.01)$ effect in all treatment groups than the $\mathrm{G}_{1}$ group and it is presented in Table 9.Findings of the present study are in agreement with Sharma (2010), who reported significant $(\mathrm{P} \leq 0.05)$ effect of supplementation of polyherbal on milk solid not fat per cent in karan fries cows. Soni (2014), also reported highly significant $(\mathrm{P} \leq 0.01)$ effect of shatavari supplementation on milk solid not fat per cent in kankrej cows.

\section{Milk solid not fat yield}

Statistical analysis of data revealed highly significant $(\mathrm{P} \leq 0.01)$ effect due to treatment and is presented in Table 10.Soni (2014) also reported highly significant $(\mathrm{P} \leq 0.01)$ effect of shatavari supplementation on milk solid not fat yield in kankrej cows.

\section{Milk total solid}

The statistical analysis of data revealed highly significant $(\mathrm{P} \leq 0.01)$ effect on milk total solid due to treatment and is presented in Table 11. Kumar et al., (2014) also reported significant effect of shatavari on per cent milk total solid in karan fries crossbred cows. Divya et al., (2015) also reported significant effect of shatavari on per cent milk total solid in indigenous cows.

\section{Milk total solid yield}

The statistical analysis of data revealed highly significant $(\mathrm{P} \leq 0.01)$ effect due to treatment and is presented in Table 12. Findings of the present study are in agreement with Soni (2014), who reported highly significant $(\mathrm{P} \leq 0.01)$ effect of shatavari supplementation on milk total solid yield in kankrej cows.

In the present study, the effects of herbal feed supplement shatavari (Aspargus racemosus) were assessed in terms of qualitative and quantitative parameter of milk, in crossbred cows. In the diet of crossbred cows led to better output in all supplemented groups that is $40 \mathrm{gm} /$ day, $80 \mathrm{gm} /$ day and $120 \mathrm{gm} /$ day. Although there was no significant difference between the supplemented groups but the most cost effective feeding of the herbal feed supplement shatavari was found in $\mathrm{G}_{2}$ group (40 gm/day).

\section{References}

Bakshi, M.P.S. and Wadhwa, M. (2000). Feed additives that modify animal performance. In Rumen microbial ecosystem and its manipulation techniques (Eds. D.N. Kamra, L.C. Chaudhary and N. Aggarwal), IVRI, Izatnagar, India, pp 125 - 134.

Bakshi, M.P.S., Neelam Rani, Wadhawa, M., and Kushal, S. (2004). Impact of herbal feed additive on the degradability of feed stuffs in vitro, Indian j. Animal Nutri. 21: 249-253.

Divya, K. K, Chaudhary, P. L., Khare, A., Chaudhary, K. K., Sexena, R. R., Shukla, N., Bharati, K. A. and Kumar 
A. (2015). Effect of feeds supplemented with Asparagus racemosus on milk production of indigenous cows. Mintage Journal of Pharmaceutical and medical sciences. 1(1): 1-6.

Gabay M. P. Galactagogues: Medications that induce lactation J Hum. Lact 2002. 18(3): 274-279.

ICAR, (2013). Nutrient requirement of livestock and poultry. ICAR, New Delhi.

Krishana, L., Swarup, D. and Patra, R. C. (2005). An overview of prospects of ethano-veterinary medicine in India. Indian J. Anim. Sci. 75(12): 1481-1491.

Kumar, S., Mehla, R. K., and Singh, M., (2014). Effect of shatavari (Asparagus racemosus) on milk production and immune-modulation in karan fries crossbred cows. Indian Journal of Traditional Knowledge. 13(2): 404-408.

Mishra, I. S., Jaiswal, R. S., Bhardwa, R. K., Sharma, R. J., Joshi, Y. P., Mondal, B. C. and Rahal, A. (2008). Effect of feeding shatavari (Asparagus racemosus) on nutrients intake, digestibility and milk production in crossbred lactating cows. National Seminar on Emerging Opportunities for Commercialization in dairy (6-7Nov), NDRI, Karnal, Haryana-132001, India.
Ramesh, P. T., Mitra, S. K., Suryanarayna, T. and Sachan, A. (2000). Evaluation of Galactin, an herbal galactagogue preparation in dairy cows. Veterinarian. 2(4): 1-3.

Ravikumar, B. R. and Bhagwat, V. G. (2008). Study of the influence of Galactin Vet Bolus on milk yield in lactating dairy cows. Livestock Line. p. 5-7.

Soni, M., Kumar, V., Goswami, S.C., Jain, M. and Rana S. (2016). Effect of shatavari supplementation on fat percentage and fat yield in the milk of kankrej cows. Veterinary Practitioner. 17 (2): 280281.

Sridhar, N. B. and Bhagwat, V.G. (2007). Study to assess the efficacy and safety of Galactin Vet bolus in lactating dairy cows. Mysore Journal of Agricultural Sciences. 41 (4): 496- 502.

Tanwar, P. S, Rathore, S. S. and Kumar, Y. (2008). Effect of shatavari (Asparagus recemosus) on milk production in dairy animals. Indian J Anim Res. 42: 232233.

Uegaki, R., Ando, S., Ishida, M., Takada, D., Shinokura, K. and Kohchi, Y. (2001). Antioxidant activity of milk from cows fed herbs. Nippon Nogeikagaku Kaishi. 75(6): $669-671$.

\section{How to cite this article:}

Vijay Prakash Saini, Sheela Choudhary, Reenu Tanwar, Sunil Dutt Choudhary, Surya Prakash Sirvi and Vikram Singh Yadav. 2018. Effect of Feeding Shatavari (Asparagus racemosus) Root Powder on Qualitative and Quantitative Parameter of Milk in Crossbred Cows. Int.J.Curr.Microbiol.App.Sci. 7(08): 3265-3277. doi: https://doi.org/10.20546/ijcmas.2018.708.348 